\title{
Schema adjustment and Holy Communion: A transdisciplinary approach
}

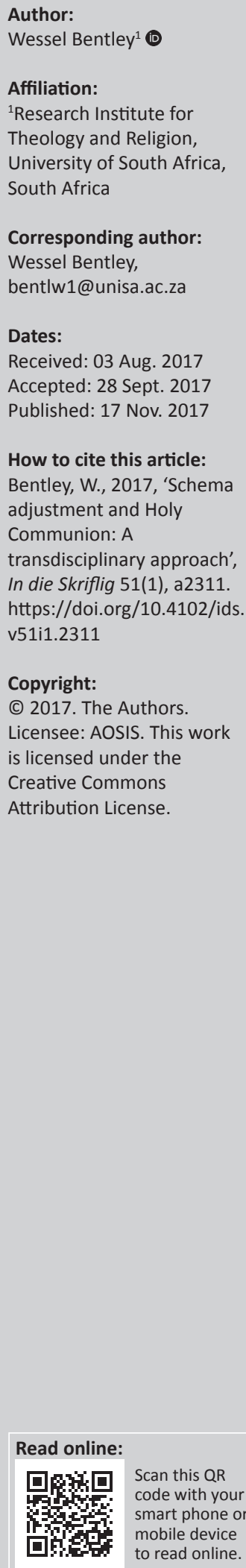

\begin{abstract}
In his sermon entitled 'The means of grace', John Wesley proclaimed that Christians should consider the Sacrament of Holy Communion as an event through which a person is exposed to God's life-transforming grace. The research question posed by this article is whether Holy Communion can attain change in an individual. Using a transdisciplinary approach, this article explores how Holy Communion in the Methodist tradition can be used for schema formation and/or schema adjustment.
\end{abstract}

\section{Introduction}

In the changing social realities of a country such as South Africa, the role of religion in social transformation is increasingly coming under the spotlight (see Barnard et al. 2010). The Christian religion, of which Methodism is but one tradition, has a rich history of influence in social development. The Methodist tradition emphasises the point that personal spirituality needs to find expression in social structures and behaviour (see Forster 2008). One of the primary instruments of 'change' in Methodism - on both a personal and a community level - is found in and through the Sacrament of Holy Communion.

Regarding Holy Communion, John Wesley (1987:124-139) proposed that this sacrament be seen as 'a means of grace' and a converting ordinance (see Wesley 1831:280-281). To Wesley (1831:280), this meant that the Sacrament of Holy Communion is an event through which a person experiences the presence of God, is confronted with the reality of his or her sin and finds grace that will lead the person to change his or her sinful ways. ${ }^{1}$ Wesley (1732) was convinced of the efficacy of the Sacrament of Holy Communion and thus proposed that it be celebrated as often as possible. ${ }^{2}$

In time, Wesley's focus on social holiness, which included regular participation in the Sacrament of Holy Communion, yielded a Christian movement in England (and later, further abroad) that contributed to significant personal and social change. To Wesley, righteous living was not just a matter of doing good deeds or performing the correct actions - it required a change in the inner person, which would lead naturally to the outflowing of a righteous life (Maddox 1996:154). Holy Communion facilitates this process of personal transformation by allowing participants to reevaluate both their place in the community and their relationship with God (Wesley 1987:133).

Of course, one may be sceptical about his conviction of the sacrament's 'power' to change a person: can a leopard ever really change its spots? Besides the religious significance of the Sacrament of Holy Communion, is it possible to find any other reason why the practise of the sacrament may contribute to personal and social change? This article argues that in the Methodist use of Holy Communion, we find elements similar to those of the social psychological theories of schemas and schema adjustment. Schema adjustment, in particular, is an instrument that aims to transform existing maladaptive worldviews and beliefs. To argue the hypothesis that Holy Communion can be seen as a life-transforming religious ritual, the theories of schema and schema adjustment will first be described before moving on to a description of important points in the theology of Holy Communion in the Methodist tradition. Thereafter, elements of schema

1.In John Wesley's journal entry of 28 June 1740 , he recorded the following

I showed at large, (1) That the Lord's Supper was ordained by God, to be a means of conveying to men either preventing, or justifying, or sanctifying grace, according to their several necessities. (2) That the persons for whom it was ordained, are all those who feel that they want the grace of God, either to restrain them from sin, or to show their sins forgiven, or to renew their souls in the image of God. (3) That inasmuch as we come to this table, not to give him any thing, but to receive whatsoever he sees best for us, there is no previous preparation indispensably necessary, but to desire to receive whatsoever he pleases to sees best for us, there is no previous preparation indispensably necessary, but to desire to receive whatsoever he pleases to
give. And, (4) That no fitness is required at the time of communicating, but a sense of our state, of our utter sinfulness and give. And, (4) That no fitness is required at the time of communicating, but a sense of our state, of our utter sinfulness and
helplessness; every one who knows he is fit for hell, being just fit to come to Christ, in this as well as all other ways of his helplessness; every one who knows
appointment. (Wesley 1831:280)

2.John Wesley first used the thoughts of this sermon in his teaching on Holy Communion to his students at Oxford. It only later took the form of a sermon, possibly preached on 19 February 1732 . 
adjustment will be outlined in the context of Holy Communion in the Methodist tradition. This article falls within the ambit of science and religion with specific reference to scientific theory in psychology and the Christian doctrines of soteriology and ecclesiology.

\section{Schemas and how they function}

Social psychology proposes that people use cognitive tools, called 'schemas', to observe, understand and respond to their environment. Schemas, by definition, are 'mental structures that help us to organise social information and that guide the processing of that information' (Baron, Byrne \& Branscombe 2005:42). In turn, schemas contribute to the formation of beliefs which direct notions of self, reality and relationships (Baumeister 1995:58).

Before this article commences with a discussion on schemas, the use thereof needs to be clarified. I acknowledge that there are different interpretations and applications of schemas and schema theory. These include, among others, theories by Clark et al. (2010), ${ }^{3}$ Piaget (2003:20-57), ${ }^{4}$ and Young, Klosko and Weishaar (2003). ${ }^{5}$

This article employs a definition of schemas as described by Baron et al. (2005) who argue that schemas are associated with the recognition of patterns or other stimuli in one's environment which, in turn, evokes expectations and/or behavioural responses. Where Piaget (2003) and Clark et al. (2010) (in particular) place an emphasis on schema building during child development, Baron et al.'s definition (2005) suggests that schemas are a learning tool, employed to ease information processing, but not limited to a child's developmental phases. It is with this definition in mind that schema building can be described as a valuable cognitive tool which assists people to know, interact with and respond to their environment. It is the brain's way of creating shortcuts through which it can quickly process and respond to presented stimuli. It does so by identifying patterns that are familiar to the observer and eases the processing of information by means of association.

To give an example: take for instance the experiences of a person travelling to an airport, preparing to fly to a foreign destination. For a person traveling by air for the first time, the process of arriving at the airport, checking in, making their way to the designated gate, and so on, can be an overwhelming experience. Each aspect of the journey is new and is received as 'original' information. For some individuals, exposure to a magnitude of new information may elicit feelings of anxiety and fear, and might even leave them unable to work out the process or appropriate responses needed in order to complete the journey - from accessing the terminal to boarding the

\footnotetext{
3.Clark et al. refer to memory systems shaped by the interplay between emotion and the brain's biology.

4.Piaget uses the term groupings to refer to cognitive structures used to organise mental processes.

5.Young et al. refer to maladaptive schemas, especially in child development, which lead to behavioural characteristics in adulthood.
}

plane. Not to mention the process of disembarking, finding their luggage and making their way to the next venue. By going through the experience, the first-time traveller will start the process of building a schema so that when he or she has to travel again, there is a 'memory-roadmap' in place that will help make subsequent travel a bit easier. On the other hand, for the seasoned traveller just the mention of a trip by aeroplane will awaken the well-entrenched 'roadmap' (schema) which will leave this person less anxious about the process of the journey; they know what to expect when they arrive at the airport. The person anticipates these events as a mental image that was built using a rehearsed frame of reference, falling back on personal past experiences and gained knowledge.

The use of schemas as described in this example significantly reduces the person's efforts to observe and respond to their environment. The converse is also true: imagine for a moment that, despite having been exposed to the same stimulus on several occasions, the person concerned is unable to build schemas. The absence of schemas would require an enormous amount of time and energy from the observer to process each stimulus and experience anew. Young et al. (2003:7) describe the use of schemas in the following way: '... a schema can also be thought of as an abstract cognitive plan that serves as a guide for interpreting information and solving problems'. From a cognitive-processing perspective, the 'brain is an anticipation machine' (Siegel 2007:187), drawing on past experience and exposure in order to respond to the stimuli and environment of the present.

Schemas have a profound impact on how we perceive reality and readily respond to our environment. They are not solely applicable to events, but to any stimulus. A person may, for instance, when meeting another person who bears a striking resemblance to someone who evokes negative memories, display less openness to this person than if no such resemblance existed at all (Devine 1995:476-478). This is the domain of implicit personality theory. In this theory, we assume that personal characteristics go together with categories or the distinctive features of people whom we may encounter such as attributing demeaning generalisations to people of a specific gender, culture, race or belief system (see Baron et al. 2005:110-118). Schemas are therefore used as associations or characterisations where an anticipated encounter provides the framework for efficient information processing and expedited human behavioural responses.

In summary, schemas fulfil a two-part role: first, they minimise the brain's efforts to construct an understanding of reality, by using information that fits familiar or similar stimuli or experiences; second, they shorten response rates to stimuli and experiences, based on information recalled and reconstructed from memory. We find schemas to be both useful and necessary, for instance, 'when we are trying to handle a lot of social information at one time, ... they allow us to process information with less effort' (Baron et al. 2005:44). 
As much as schemas are useful for 'filling in the blanks' (Wuthnow 2007:344), they may also lock us into perceiving the world inaccurately, for instance in the formation of stereotypes and prejudices. In the South African context, the problem of racial stereotyping and prejudice is on-going and hampers efforts aimed at social cohesion. Concerning racism, Nelson Mandela (1995) once made a valuable observation, saying:

No one is born hating another person because of the colour of his skin, his background, or his religion. People must learn to hate, and if they can learn to hate, they can be taught to love, for love comes more naturally to the human heart than its opposite. (p. 622)

Using schema theory, we can spot elements of schema formation and adjustment in this quote. First of all, the schema of racial prejudice is learnt behaviour. Second, the more an individual practises this behaviour, the deeper a schemabecomes entrenched in his or her social understanding. Third, schemas can be altered. On this point we need to be clear: schemas, whether they are socially acceptable or considered to be maladaptive, cannot be destroyed or replaced; they can simply be altered by gradual and persistent intervention. ${ }^{6}$

\section{Can schemas change?}

Social psychology suggests that it is possible for schemas to change (to be altered, but not destroyed), but it is extremely challenging to do so, as schemas form the foundation on which we see and interpret our reality. This is especially true when schemas are built on stereotypes. Baron et al. (2005) put it differently:

Because stereotypes serve as justifications for existing social arrangements, only when values and the categorizations used shift, or our stake in the present status relations is altered, should stereotypes change. (p. 224)

Schema adjustment therefore requires persistent exposure to situations or stimuli that question maladaptive interpretations (McIntosh 1995:3). Such intervention is traditionally done in the context of psychological therapy. The therapeutic process of adapting schemas, whether through cognitive, experiential or behavioural patternbreaking strategies, generally follows a certain order of events (see Young et al. 2003). It is imperative that the therapist, during the therapeutic process, act as mentor and not as instructor. Drawing alongside the patient in a relationship of trust produces interaction and cooperation which will assist with the process of internalising the adjustment of held schemas (Kim 2007:319). The process commonly unfolds in a series of steps.

First, from the patient there needs to be a 'willingness to face the schema and do battle with it' (Young et al. 2003:32). This entails a three-part introduction:

6.Cognitive Behaviour Therapy (CBT) and Mindfulness-Based Cognitive Therapy (MBCT) are examples of such interventions used in the treatment of maladaptiv schemas (see Hofmann, Sawyer \& Fang 2010; Lillis \& Hayes 2007).
1. The patient is made aware of his or her maladaptive schema;

2. The process of schema adjustment is explained;

3. In response to this information, the patient decides whether or not he or she wishes to be part of the process.

The recognition aspect of this part of the therapy entails an acknowledgement by the patient that his or her existing schema is inaccurate (Young et al. 2003:92). The therapist explains that, by gradually and persistently introducing alternative information, the patient will be able to distinguish between his or her maladaptive schema and a healthy response (adjusted schema) (Young et al. 2003:92). The patient then needs to agree to this process.

The second part of the therapy demands 'discipline and frequent practice' (Young et al. 2003:32). The therapist will introduce information that provides an alternative understanding to that which is provided by the patient's existing schema. Together, the patient and therapist will explore ways in which the alternative information can be incorporated into the patient's reality, and so facilitate new cognitive and behavioural responses. This is then practised by the patient outside the context of the therapy sessions and will provide a platform from which future therapy sessions will proceed. This means that schema therapy is not a once-off remedy, but a process of relinquishing the certainty of maladaptive schemas by questioning their universal appeal in the participant's reality. The patient, through repetition, gains a 'heightened appreciation of how distorted the schema actually is' (Young et al. 2003:92), and through the repetition of alternative responses, makes adaptations to the schema that are more personally and socially acceptable.

To conclude this section, schemas are mental constructs that assist us in interpreting and responding to our world. The more schemas are practised, the more they become normative in our understanding of our environment and our responses to it. Maladaptive schemas are treatable by conscious and persistent efforts targeted at considering and implementing alternative information with the aim of subsequently adjusting those schemas. Practising altered behaviour is therefore transformative (Ryan 2005:58).

\section{Holy Communion in the Methodist tradition}

First, an admission: I specify the use of the Sacrament of Holy Communion in the Methodist tradition, as this is the tradition I belong to as an ordained minister. The process of practising Holy Communion may very well be similar in other Christian traditions, but this is the context I speak from. Second, given the Methodist church's racial diversity in membership, a focus on ministry as bridge-building in multicultural congregations is of the utmost importance, especially seeing that as South Africans we have a history of well-entrenched racial schemas which make social 
integration challenging (see Bentley 2012; 2014). Although it is possible to address the maladaptive schema of racial prejudice on its own in this comparison between Holy Communion and schema adjustment, Ibelieve the application could be administered in broader terms to also address other maladaptive schemas.

Another admission is that we should recognise that religion itself is a schema. Those who have been brought up in a particular religion or who may have had a profound religious experience, build an understanding of self, God and others, and use this belief system to interpret the world around them (McIntosh 1995:7). The application of our belief system in general life circumstances provides a platform from where we respond - as individuals - to external stimuli (Kim 2007:312). Someone with a well-delineated concept of their belief system is more likely to integrate those religious beliefs in his or her daily life (McIntosh 1995:8).

If religion is a schema or contributes to schema formation in the individual and/or community, then, as Leffel (2008:185) argues, religion and religious practices may trigger selfreflective moral intuitions which, in turn, magnify and promote moral behaviour. Sachs Norris (2005:196) takes this thought a step further by suggesting that when a person belongs to and participates in a religious culture, such belonging and participation have the capacity to communicate values, experiences and ideas which may impact on the individual in a potentially profound (and life-changing or schema-adjusting) way.

To get back to Holy Communion in the Methodist tradition: one of the appealing and significant characteristics of the Methodist usage of Holy Communion is that that tradition promotes an Open Table theology. This means that any person who wishes to participate in the sacrament is welcome to do so and is not prohibited on account of his or her membership status, ecclesiastic affiliation or standing in the community (Methodist Church of Southern Africa 2014:15-16). This invitation even extends to children who are part of the worshipping community (Methodist Church of Southern Africa 2014:18-19). This point is significant, for it suggests that any person who seeks to be included in this 'means of grace' is welcome to do so. Communion is not reserved for the righteous or those who qualify to partake, but is accessible to any person who is willing to participate.

It is in and through the Sacrament of Holy Communion that the community participates in a religious ritual which commemorates the death and resurrection of Jesus Christ 'through which they receive forgiveness for their sins and the salvation of their souls' (Methodist Church of Southern Africa 2014:15). The sacrament therefore speaks about the letting go of one aspect of the participant's life in order to embrace something new. But, besides the theological reflection and understanding of the Sacrament of Holy Communion, the process of the celebration itself can be described in schema-adjustment terms.

\section{Schema-adjustment processes in Holy Communion}

For the purposes of this article, the focus is on identifying schema-adjustment processes in the liturgy for Holy Communion as described in The Methodist Service Book (Methodist Conference Office 1975). Although there are several liturgies in use for the celebration of Holy Communion in the Methodist tradition, this is the most commonly used in the English medium. The process followed in the liturgical structure is indicative of the process of schema adjustment through psychological therapy and, when used by the presiding minister with this understanding in mind, it will be a challenging encounter for the participant. The liturgy is divided into four distinct sections:

1. The preparation;

2. The ministry of the Word;

3. The celebration; and

4. The concluding prayers.

\section{The preparation}

The first part of the communion liturgy is called 'The preparation'. During this time, the congregation is led in a prayer which allows individuals to make themselves receptive to the Word of God. The Commandments are then read, followed by a prayer of confession and absolution. To superimpose schema therapy, one could suggest the following: The preparation is an open invitation to anyone who seeks to engage in the process of self-evaluation. The opening prayer leads the congregant to an attitude of subjective self-assessment, as the prayer suggests that God is able to objectively encounter each person as he or she is. The opening prayer reads as follows:

Almighty God, to whom all hearts are open, all desires known, and from whom no secrets are hid: cleanse the thoughts of our hearts by the inspiration of your Holy Spirit, that we may perfectly love you, and worthily magnify your holy Name; through Christ our Lord. Amen. (Methodist Conference Office 1975:B5)

As the members of the congregation reflect on their own being - their existing schemas - through this prayer, the Commandments are then read. This reading offers an indication to the individual and the community of maladaptive schemas which may be present. The congregational response of 'Lord, have mercy upon us, and incline our hearts to keep this law' (Methodist Conference Office 1975:B23) is a recognition of any existing maladaptive schemas or behaviours and offers an intention for these realities to be amended. The reading of the Commandments is followed by the conscious step of vocalising the intention to move from old habits to new with the promise that a justified, adjusted schema is indeed possible (prayer of absolution): 'Christ Jesus came into the world to save sinners. Hear then the word of grace: Your sins are forgiven. Amen. Thanks be to God' (Methodist Conference Office 1975:B6). 


\section{The ministry of the Word}

'The preparation' is followed by 'The ministry of the Word'. In this part of the service, passages are read from the Bible, followed by the sermon. It is the point of the ministry of the Word to proclaim the gospel of God's life-transforming grace in light of the 'sins' (maladaptive schemas) that plague us. It is this grace that convicts us of our sin, and edifies and challenges us as individuals and community to live in a particular way. In effect, the ministry of the Word holds before the individual and community an alternative to the maladaptive schemas and behaviours identified and confessed during 'The preparation'.

The ministry of the Word then takes a turn; it moves the individual and community from inward reflection to the outward identification of how maladaptive schemas impact on the world around us. This is done through the prayers of intercession. These prayers direct the congregation's focus to the church, 'the peoples of the world and their leaders', society and those who have authority, those among whom we live and work, and for those who find themselves in need (Methodist Conference Office 1975:B7-B8). Each part of the prayer identifies maladaptive behaviour and asks for an alternate reality (adjusted schema). At the same time, the congregation is invited to look around and recognise those who participate alongside them in this sacrament. It may well be that individuals recognise that they will be sharing in the sacrament with people whom they themselves would not usually invite to their own tables. The nature of the Open Table is emphasised, as was so eloquently done by the Reverend Joanna Cornelius (pseudonym), when she said:

We practice an Open Table ... That's why I love the United Methodist Church, because we are all welcome - the abled and the disabled, the law breakers and the law makers ... All are welcome. That's how we beat swords into ploughshares. (Stamm 2006:x)

Not only is the congregation urged to identify those present, but also to take note of who is conspicuously absent (Felton 2006:31-32). The reason for their absence may very well be as a result of the persistence of maladaptive schemas in society (or in the congregation!). If at any point in the service there is a time where the congregant and congregation hold their existing schemas and the schema of the gospel side by side, it is in this moment.

The ministry of the Word concludes with a dramatic event. The congregation is invited to make a decision: to continue with the sacrament as a symbolic practice of substituting their maladaptive schemas with the schema presented by the Word, or to be excused. The decision to be excused may not necessarily be a refusal to participate in the process of change, for some may feel that they could not participate while unfinished business needs to be attended to. The presiding minister, at this point, offers a blessing: 'The grace of the Lord Jesus be with you all. Amen' (Methodist Conference Office 1975:B9), after which those who choose to leave are welcome to do so.

\section{The celebration}

Those who remain for the sacrament are asked to share the peace with one another - an active form of practising the alternative reality of the gospel (thus enabling a rejection of the maladaptive schemas of society). Congregants greet one another with the words: 'The peace of the Lord' (Methodist Conference Office 1975:B10), followed by the reciting of the Nicene Creed which, at this point, establishes a verbal commitment by each participant as belonging to a community of faith which holds fast to certain beliefs, norms and responsibilities - both inside the community of faith as well as beyond this sacramental event (this is who we are and what we believe).

The liturgy in the setting of the table continuously juxtaposes human sinfulness with the alternative reality offered by the gospel, that is, describing maladaptive schemas as undesirable, while promoting the notions of forgiveness, inclusion, justice, reconciliation and righteous living. Here are a number of examples (Methodist Conference Office 1975:B12-B15):

'made us in your own image' (alternative) versus 'we had fallen into sin' (maladaptive);

'He shared our human nature, and died' (alluding to Jesus identifying with maladaptive identity, although Christ did not $\sin$ ) versus 'You raised him from the dead' (alternative);

'we had fallen into sin' (maladaptive) versus 'make us one body with him' (alternative);

'we are not worthy to gather up the crumbs' versus 'feed us with the body and blood of Jesus Christ your Son, that we may forever live in him and he in us'.

As the congregation gathers to participate in the Sacrament of Holy Communion, the act of 'Coming to the Table' is an active response by the person and community to commit to change. The meal itself is symbolic of the eschatological point of healing for both the individual and the community, as the congregation prays: 'We thank you, Lord, that you have fed us in this sacrament, united us with Christ, and given us a foretaste of the heavenly banquet for all humankind [sic]' (Methodist Conference Office 1975:B17).

\section{The concluding prayers}

For the individual and the community, the process of transformation (or schema adjustment) is not yet complete. The minister concludes the service by pronouncing 'The blessing of God, Father, Son and Holy Spirit, remain with you always. Amen. Go in peace in the power of the Spirit to live and work to God's praise and glory. Thanks be to God' (Methodist Conference Office 1975:B17). This benediction, like the latter part of schema therapy, encourages both discipline and frequent practise, as the reality of the 'gospel-schema' is to be exercised throughout the week, 
TABLE 1: Comparison of schema adjustment and Holy Communion.

\begin{tabular}{|c|c|}
\hline $\begin{array}{l}\text { Psychological process of schema } \\
\text { adjustment }\end{array}$ & $\begin{array}{l}\text { Liturgy and celebration of Holy } \\
\text { Communion }\end{array}$ \\
\hline $\begin{array}{l}\text { Creating a safe space for the individual, } \\
\text { facilitating introspection } \\
\text { Making the person aware of their } \\
\text { maladaptive schema }\end{array}$ & $\begin{array}{l}\text { Opening prayers } \\
\text { Reading of Commandments } \\
\text { Prayers of confession } \\
\text { Reading of Scripture } \\
\text { Proclamation of the Word }\end{array}$ \\
\hline $\begin{array}{l}\text { Providing alternative information to } \\
\text { challenge existing schemas }\end{array}$ & $\begin{array}{l}\text { Proclamation of the Word } \\
\text { Prayers of intercession } \\
\text { Identifying who is present } \\
\text { Identifying who is absent }\end{array}$ \\
\hline $\begin{array}{l}\text { Deciding whether to participate in therapy } \\
\text { or to continue with existing schema }\end{array}$ & $\begin{array}{l}\text { Deciding whether or not to partake of } \\
\text { Communion }\end{array}$ \\
\hline Practising the adjusted schema & $\begin{array}{l}\text { The sharing of the peace } \\
\text { Participating in the sacrament }\end{array}$ \\
\hline Repeating the adjusted schema & $\begin{array}{l}\text { Dismissal and encouragement to 'live } \\
\text { out the faith' } \\
\text { Repeated participation in the } \\
\text { Sacrament of Holy Communion }\end{array}$ \\
\hline
\end{tabular}

until the congregation once again meets around the table to remind themselves of their participation in the process of sanctification.

It is by repetitively participating in the sacrament (with the deliberate focus on identifying maladaptive schemas, providing alternative information, the opportunity to tacitly practise adjustment through the physical experience of communion), that the 'new reality' in the individual is reinforced (Sachs Norris 2005:191). As with schema formation, the more the adjusted schema is emphasised and repeated, the more natural it becomes for the individual to use as a normative frame of reference.

In order to visualise the comparative processes of schema adjustment through therapy and the challenge of personal and communal change through the Sacrament of Holy Communion, Table 1 seeks to illustrate the similarities.

\section{Conclusion}

This article has aimed to identify similarities between the processes of schema adjustment and a change in the person which is believed to be facilitated through the Sacrament of Holy Communion in the Methodist tradition. First, a definition of schema theory was provided to bring across the point that cognitive frameworks are commonly used in both helpful and maladjusted ways. Maladjusted schemas are not only inaccurate ways of interpreting the world around us, but have significant effects on the individual and society at large. Maladjusted schemas are adjusted in a therapeutic process by means of an individual recognising their own maladjusted schemas, engaging with alternative information and practising alternative responses to the point where their adjusted schema becomes their normative frame of reference.

It is subsequently argued that the liturgy of Holy Communion in the Methodist tradition displays a similar process: leading congregants from the point of recognising their own 'sin', to being exposed to the alternative information provided by the gospel and then practising this alternative way of life through participating in the Sacrament of Holy Communion.
I therefore agree with John Wesley's belief that Holy Communion can be seen as a means of grace on a religious level, but also through an existential process of facilitating self-reflection and self-assessment, by considering alternative potentials and being offered the opportunity to practically incorporate these alternative potentials. Through repetition by means of Holy Communion, personal transformation and schema adjustment are certain probabilities.

\section{Acknowledgements Competing interests}

The author declares that he has no financial or personal relationships which may have inappropriately influenced him in writing this article.

\section{References}

Barnard, M., Swart, I., Ter Haar, G. \& Wepener, C., 2010, 'The role of religious ritual in social capital formation for poverty alleviation and social development. The theoretical and methodological points of departure of a South African exploration', Religion and Theology 17(1), 61-82. https://doi.org/10.1163/1574 $30110 \times 517924$

Baron, R.A., Byrne, D.R. \& Branscombe, N.R., 2005, Social psychology, 11th edn., Allyn \& Bacon, Boston, MA.

Baumeister, R.F., 1995, 'Self and identity: An introduction', in A. Tesser (ed.), Advanced social psychology, pp. 51-98, McGraw-Hill, New York.

Bentley, W., 2012, 'The place of the Church in the new South Africa', in W. Bentley \& D.A. Forster (eds.), Between capital and cathedral: Essays on church-state relationships, pp. 89-103, Research Institute for Theology and Religion, Pretoria.

Bentley, W., 2014, 'Ministry as bridge building: Facilitating culturally diverse faith communities in South Africa', in R.D. Smith, W. Ackah \& A.G. Reddy (eds.), Churches, blackness and contested multiculturalism: Europe, Africa and North Churches, blackness and contested multiculturalis
Africa, pp. 145-157, Palgrave Macmillan, New York.

Clark, J.D., LeDoux, T., Richardson, T. \& Winterowd, C., 2010, 'Relationship of negative self-schemas and attachment styles with appearance schemas', Body Image 7(3), 213-217. https://doi.org/10.1016/j.bodyim.2010.02.003

Devine, P.G., 1995, 'Prejudice and out-group perception', in A. Tesser (ed.), Advanced social psychology, pp. 467-524, McGraw-Hill, New York.

Felton, G.C., 2006, 'Holy Communion in the life of the Church: The theology and experience of reconciliation', in T.W. Porter (ed.), Conflict and communion: Reconciliation and restorative justice at Christ's Table, pp. 25-35, Discipleship Resources, Nashville, TN.

Forster, D.A., 2008, 'Prophetic witness and social action as holiness in the Methodist Church of Southern Africa's mission', Studia Historiae Ecclesiasticae 34(1), 411434.

Hofmann, S.G., Sawyer, A.T. \& Fang, A., 2010, 'The empirical status of the "new wave" of Cognitive Behavioural Therapy', Psychiatric Clinics of North America 33(3), 701-710. https://doi.org/10.1016/j.psc.2010.04.006

Kim, J., 2007, 'Cognition and faith formation: A reflection on the interrelationship of schema, thema and faith', Christian Education Journal 4(2), 308-321.

Leffel, G.M., 2008, 'Who cares? Generativity and the moral emotions, part 2: A "social intuitionist model" of moral motivation', Journal of Psychology and Theology 36 182-201.

Lillis, J. \& Hayes, S.C., 2007, 'Applying acceptance, mindfulness, and values to the reduction of prejudice: A pilot study', Behavior Modification 31(4), 389-411. https://doi.org/10.1177/0145445506298413

Maddox, R.L., 1996, 'Holiness of heart and life: Lessons from North American Methodism', Asbury Theological Journal 51, 151-172.

Mandela, N., 1995, Long walk to freedom: The autobiography of Nelson Mandela, Back Bay Books, New York.

McIntosh, D.N., 1995, 'Religion-as-schema, with implications for the relation between religion and coping', International Journal for the Psychology of Religion 5(1), 1-16. https://doi.org/10.1207/s15327582ijpr0501_1

Methodist Church of Southern Africa, 2014, The methodist book of order: The laws and discipline of the methodist church of Southern Africa, 12th edn., Methodist Publishing House, Cape Town.

Methodist Conference Office, 1975, The methodist service book, Methodist Publishing House, Peterborough.

Piaget, J., 2003, The psychology of intelligence, Routledge, Abingdon.

Ryan, T., 2005, 'Revisiting affective knowledge and connaturality in Aquinas', Theological Studies 66, 49-68. https://doi.org/10.1177/004056390506600103

Sachs Norris, R., 2005, 'Examining the structure and role of emotion: Contributions of neurobiology to the study of embodied religious experience', Zygon 40(1), 181-199. https://doi.org/10.1111/j.1467-9744.2005.00652.x 
Siegel, D.J., 2007, The mindful brain, Norton, New York.

Stamm, M.W., 2006, Let every soul be Jesus' guest: A theology of the Open Table, Abingdon Press, Nashville, TN.

Wesley, J., 1732, The sermons of John Wesley - Sermon 101: The duty of constant Communion, The Wesley Centre Online, viewed 03 August 2017, from http:// wesley.nnu.edu/john-wesley/the-sermons-of-john-wesley-1872-edition/sermon101-the-duty-of-constant-communion/
Wesley, J., 1831, Wesley's works, vol. 1, Wesleyan Methodist Book-Room, London.

Wesley, J., 1987, Sermons on several occasions: Translated into modern English, J.D. Holway (ed.), Moorley's Print \& Publishing, Ilkeston.

Wuthnow, R., 2007, 'Cognition and religion', Sociology of Religion 68(4), 341-360. https://doi.org/10.1093/socrel/68.4.341

Young, J.E., Klosko, J.S. \& Weishaar, M.E., 2003, Schema therapy: A practitioner's guide, The Guilford Press, New York. 